\title{
LOSONCZI ÁGNES: UTAK ÉS KORLÁTOK AZ EGÉSZSÉGÜGYBEN
}

(MTA Stratégiai kutatások. Budapest 1998, p. 243)

\section{IZSÁK ÉVA}

A „Magyarország az ezredfordulón” c. stratégiai kutatások keretében a Magyar Tudományos Akadémia által támogatott, „Az életminöség tényezői Magyarországon" programban jelent meg Losonczi Ágnes könyve. A szociológus szerzö már korábbi kutatásai során is nagyfokú érzékenységgel és hozzártéssel elemezte az egészségügy és a társadalom bonyolult kapcsolatrendszerét, hatásmechanizmusát, valamint ezek változásait. A most megjelent könyv azonban több szempontból is hiánypótló. A kőtet a társadalmi jelenségek oldaláról próbálja feltárni a magyar egészségügyi rendszer válsághelyzetének ősszetevóit. Választ keres - többek között - arra, hogy a közel- és régmúlt milyen mértékben tehetô felelössé a kialakult helyzetért. Szociológiai szempontból elemzi, hogy a magyar társadalmi fejlödés során milyen tényezők játszottak szerepet az európai összehasonlításban is különösen rossz morbiditási és mortalitási helyzet kialakulásában. A kötet négy nagyobb fejezete, valamint a hozzákapcsolódó 102 jegyzet, és a részletes, mind a hazai, mind pedig a nemzetközi szakirodalom színe-javát felsorakoztató irodalomjegyzék szakaszokra bontva elemzi, hogy mi történt az „egészség ügyében” a szocialista rendszer deklarált megszünése óta.

Az első fejezet („Egészségügyi válság, romló népegészség”) két, egymástól ugyan elkülönült, de szervesen òsszetartozó részben vizsgálja a mai állapothoz vezető út kezdeti szakaszát, annak elemeit és ősszefüggéseit. Ismerteti a fejlett ipari országok egészségügyi rendszerét, és annak gondjait, valamint az ebböl ránk háruló problémákat. Korrekt és átfogó elemzést ad az ,általános, egyenlö, ingyenes" szocialista egészségügyi ellátásról, annak vívmányairól és hátrányairól. A fejezet második része a népegészség állapotával foglalkozik. Összehasonlítja az Elbától keletre és nyugatra fekvő országok népmozgalmának fóbb mutatóit és igyekszik magyarázatot találni a számok mőgőtt meghúzódó ősszefüggésekre. A fejezet talán „legmerészebb", de ugyanakkor egyik legértékesebb részében kísérletet tesz a szerzó a romlás okainak indoklására. A szerzo „egy társadalmi értelmezési kísérlet” alapján tơbbek kőzőtt - így ad választ saját kérdéseire: „A társas támogatás az ember elemi szükségletei kőzőtt számon tartott elsőrendü védelmi rendszer (social support), s hiánya külơnféle megbetegedésekhez vezet. A többiek léte és az együttélés társadalmi támasza jelentheti azt a védelmet, ami az ember egészségének és biztonságra törekvésének az alapja lehet."

A második rész („Az átalakulás induló reménye - változások, viták, viharok”) az egészségpolitikai útkeresésekröl szól. Megismerhetjük a rendszerváltozás kezdetén zajló eseményeket, osszehasonlítást kaphatunk az egyes pártok programjaiban levő 
hasonlóságokról és különbségekröl. Kronologikus rendszerben áttekinthetjük az egészségügy átalakítására tett intézkedéseket 1989 és 1997 közöttt.

A harmadik részben (,Tettek és ideológiák - a konzervatív-keresztény kormány”) megismerhetjük az Antall-kormány törekvéseit az egészségügyi intézményrendszer átalakítására, így többek közőtt a háziorvosi szolgálat bevezetését előnyeivel és hátrányaival. Az abortuszvita kapcsán jól nyomon kővetheti az olvasó az 1990-94 közötti törvénykezés menetét, a viták és az azokhoz kapcsolódó beavatkozások történetét.

Az utolsó fejezet (,Kényszer és módszer - a szocialista-liberális kormány) a Horn-kormány négy esztendeje alatt történt változásokról szól, melyek középpontjában az anyagi helyzet szülte kényszermegoldások állnak. A fejezet végén „swotanalízishez" is méltó részletes képet ad Losonczi Ágnes a rendszer összetevőiröl. Elemzi annak hiányosságait, értékeit és az ezekben rejlö lehetőségeket. A fejezet végén felteszi a kérdést, hogy „van-e további út?”, majd a könyvet így zárja: „...egy jámbor kutató, aki a jelen megértésének és megértetésének nehézségeivel küszködik, de a jövőbe látás nem szakmája, az elemzés után megáll, és csak csendben fohászkodhat, remélve, hátha erre a területre is érvényesíteni lehetne az orvoslásban ismert tanult óvást, hogy: «nil nocere», "legalább ne ártsunk, ha segíteni nem is mindig tudunk»s." Ezek után az olvasó leteheti ezt a valóban sok szempontból hiánypótló könyvet és elgondolkozhat azon, hogyan lehetséges az, hogy bár egészségesek vagyunk, mégsem érezzük jól magunkat ezekben a bizonytalan körülményekben. A könyvben benne van a megoldás, csak figyelmesen el kell olvasni, és akkor megtaláljuk! 